INTERNATIONAL JOURNAL OF RESEARCHES IN BIOSCIENCES, AGRICULTURE AND TECHNOLOGY

(C) VISHWASHANTI MULTIPURPOSE SOCIETY (Global Peace Multipurpose Society) R. No. MH-659/13(N) www.vmsindia.org

\title{
ICHTHYOFAUNA OF DASTAPUR DAM IN MANGRULPIR, DIST. WASHIM
}

\section{Milind Devidas Kulkarni}

Department of Zoology Yashwantrao Chavan Arts \& Science College, Mangrulpir Dist. Washim.Maharashtra. dr.mdkulkarni@rediffmail.com

Abstract:

The study of the biotic components of producers and primary consumers and secondary consumers which is rich in biotic communities of dam Dastapur dam near She which is $12 \mathrm{KM}$ away from Mangrulpir, Taluka Mangrulpir Dist. Washim in Maharashtra. The study encouraged to develop fish breeding farm in these dam under investigation. Relative occurrence and economic values of fishes are discussed.

Keyw ords:-Dastapurdam, Ichtyofauna,, Zooplankton.

\section{Introduction:-}

Fishes are primary or secondary consumers in nature and fishes form a rich food for man and migratory birds and also provide several byproducts. Fish diet for man is good source of protein, fats and vitamins $\mathrm{A}, \mathrm{D}$, and $\mathrm{E}$. The Calcium, phosphorus and other elements present in it gives good taste. Fishes of inland water bodies have been studied since last century Day (1994), Talwar and Jhingran, (1991) Rao et. al. (1999), Meshram (2005). Study of zooplankton help to understand pollution level of dam and also give information about food available for fishes. This dam help to increase production of fishes to improve economic conditions of fishereman.

\section{Material and Methods:-}

Fishes from dam Dastapur which is $12 \mathrm{KM}$ away from Mangrulpir, Taluka Mangrulpir Dist. Washim were collected with the help of fisherman examined for colour pattern, preserved in $10 \%$ formaldehyde and identified following the key of Day (1994), Talwar and Jhingran, (1991). Zooplankton are collected with the help of plankton collecting net from 5 different places of water bodies and brought to laboratory for identification.

\section{Observation and Result Discussion:-}

Zooplankton assemblage specially rotifers dominated the water body, 22 species of rotifers from 13 genera have been identified Vashist and Sharma (1976). Meshram et al (2005), Arora (1966). Among copepods Cyclops concentration in the water body rich to maximum.

Table 1:- Zooplankton Communities present in Dastapur Dam.

\begin{tabular}{|l|l|l|}
\hline $\begin{array}{l}\text { Sr. } \\
\text { No. }\end{array}$ & \multicolumn{2}{|c|}{ Zooplankton } \\
\hline \multirow{4}{*}{1} & \multirow{4}{*}{ Rotifers } & $\begin{array}{l}\text { Branchionus } \\
\text { falcatus }\end{array}$ \\
\cline { 3 - 3 } & & Cephalodala \\
\cline { 3 - 3 } & & Monostyla \\
\cline { 3 - 3 } 2 & \multirow{3}{*}{ Copepod } & Rotararia \\
\hline & & Cyclops \\
\cline { 3 - 3 } & & Diaptomus \\
\hline 3 & \multirow{2}{*}{ Cladecerans } & Ceriodaphops \\
\cline { 3 - 3 } & & Leydigia \\
\hline
\end{tabular}

Table 2:- Occurrence and economic values of fishes in Dastapur Dam.

\begin{tabular}{|l|l|l|c|l|}
\hline $\begin{array}{l}\text { Sr. } \\
\text { No. }\end{array}$ & Species Name & Common Name & Relative Abundance & Economic Value \\
\hline 1 & Labeorohita & Rohu & Abundant & Commercial Food, Fine food \\
\hline 2 & CyprinusCarpeo & Common Carp & Abundant & Commercial Food, Fine food \\
\hline 3 & Cirrhinamrigala & Mrigal & Abundant & Commercial Food, Fine food \\
\hline 4 & Catlacatla & Catla & Abundant & Commercial Food, Fine food \\
\hline 5 & Wallagoattu & Lachi & Moderate & Commercial Food, Fine food \\
\hline 6 & L.calbasu & Kalbasu & Moderate & Commercial Food, Fine food \\
\hline 7 & Mystusseenghala & Tengra & Rare & Commercial Food, Fine food \\
\hline 8 & Clariusbatrachus & Magur & Rare & Commercial Food, Fine food \\
\hline 9 & Channapunctatus & PhoolDhok & Moderate & Commercial Food, Fine food \\
\hline 10 & C.merutis & Murrel & Abundant & Commercial Food, Fine food \\
\hline 11 & C. striatus & Morrul & Rare & Commercial Food, Fine food \\
\hline
\end{tabular}




\section{Discussion:-}

In this dam cladocerans showed no definite pattern (Table 1 ). The occurance of 11 species of teleost fishes belonging to order cypriniformes and ophiocephaliformes were recorded during the study period. (Table-2) The primary producers of dam water forming good food chain that influenced the intensive growth of economically valuable fishes. The fish fauna is an important aspect of fishery potential of the water body. Present study confirms fishes from order cypriniformes dominated the dam. Deep zone dominated by major carps and catfishes; it might be due to the population dynamics of zooplanktons including rotifers. The primary producers of dam water forming good food chain that influenced the intensive growth of economically valuable fishes.
Arora H. C. (1966).Cyclophosis (form variations) species of Indian Planktonic Rotifers Int. Rev. ges. Hydrobiologia. 51 (4); 623-632

Day F. (1994), The fishes of India, Burma \& Ceylon, Fourth Indian reprint. Vol. I \& II Jagmandar Book Agency, New Delhi.

Meshram et. al. (2005), Ichthyofauna of some wetland in an around Amravati Maharashtra J.Aqua.Biol.Vol. 20(2)2005:77-78

Rao et. al. (1999) Hydrobiology and Ichthyofauna of Mehadrigedda stream of Visakhapattanum, A. P. J. Aqua.Biol. Vol.13(1\&2):25-28.

Talwar, P.K. and Jhingran, A. (1991). Inland fishes of India and adjacent Countries, Oxford and IBH Publ.Co.Pvt.Ltd.,Newdelhi.Vol. I\&II.

Vashist H. S. and Sharma B. K. (1976). Seasonal abundance of rotifer population in a fresh water pond in Ambala City (Haryana) India, 28:35-44

\section{References:}

